\title{
The Influence of Seasonal Variation on the Testosterone Hormone of Black Bengal Bucks (Capra aegagrus hircus)
}

\author{
Mihir Bhatta*, Debasish Das*, ProbalRanjan Ghosh**
}

\begin{abstract}
TheBlack Bengal bucks of Indian sub-continent generally show a noted seasonal variation during in reproductiveactivity.India has a good number of Black Bengal goat populations, which has an important rolein the lives of the goat rearers. The objective of thepresent study is to comprehendtheinfluence of seasonal variation on thetestosteronehormoneof Black Bengal bucks(Capra aegagrus hircus) in two different agro-climatic zones in India. The highest mean value oftemperature $\left(42.6 \pm 1.5^{\circ} \mathrm{C}\right)$ has been reported during themonth of A pril or $\mathrm{M}$ ay in theseason of premonsoonin Purulia. However, thelowest valueof temperature $\left(8.6 \pm 0.9^{\circ} \mathrm{C}\right.$ ) has been reported during themonth ofDecember or January in the season of post-monsoon again in Purulia.Serum testosterone was analyzed in blood samples collected once a week. It has been observed that, from January to A pril for both of theregions of Purulia and $\mathrm{N}$ adia and the month $M$ ay has thelowest serum testosteronelevel in Purulia $(1.22 \pm 0.18 \mathrm{ng} / \mathrm{ml})$ and theserum testosterone levels stayed approximately the same from January to March in Purulia and more or less similar in Nadia. However, the serum testosterone level reached to its peak level in N ovember in both the region N adia $(8.79 \pm 1.3 \mathrm{ng} / \mathrm{ml})$ and Purulia $(6.59 \pm 0.41 \mathrm{ng} / \mathrm{ml})$ respectively.It can also be presumethattheearly periods of the post-monsoon season can be taken as an alternate breeding seasons for Black Bengal breeds.
\end{abstract}

Keywords: Testosterone; Bucks; Purulia; Nadia; Pre-M onsoon; Post-M onsoon.

\section{Introduction}

Seasonality of reproduction mayhavea major role on the production rateof farm animal species such as goat, cattle and sheep.The levels of the different hormones which havemajor effects on reproductive system canundergo changes very much depending upon thephotoperiodic variation[1].Theandrogens have a significant effects on the reproductive capabilities in most of the male farm animals. The testosteronehormonein a maleis much more effective as well as vital than other androgens found in an animal body. Excepttestosterone other androgen present are androstenedione and 5 alphadihydrotestosterone. They al together induce a constructive effects on physiological development through the nitrogen build-up in cells [2].Somegoat breeds from temperate latitudes exhibita seasonal variation in reproductiveactivityduring theyear[3]. Although, in Indian sub-continent it is known that monsoon is the ideal season for reproduction of most of theanimals, especially farm animals[4]. So, in this present study it is an initialeffort to establish aperiod
A uthor's Affiliation: *Department of Environmental Science, University of Kalyani, Kalyani, Nadia-741235, West Bengal, India. Telephone +919051821957. **Department of Veterinary Physiology, West Bengal University of A nimal \& Fishery Sciences, 37 Khudiram Bose Sarani, Kolkata-700037. West Bengal, India.

Reprint's Request: Debasish Das, Department of Environmental Science, University of Kalyani, Kalyani, Nadia741235, West Bengal, India.

E-mail: ddas_kly@rediffmail.com

of time except the season of monsoon as an alternate period for reproduction of Black Bengal goats. Different studies have been revealed thatthere are other environmental factors, suchas availability of food and the presence of male and female [3 and5] mayinfluencethe season of reproduction.

The objective of the present study is tocomprehendtheinfluence of seasonal variation on thetestosteronehormoneof Black Bengal bucks (Capra aegagrus hircus) [6] in two different agro-climatic regions in West Bengal, India.Moreover, this will bea probablecontribution to this field of research on Black Bengal goats where inadequate researches have been available and these results can be useful 
determine the best possibleseason of reproduction alternateto monsoon.

\section{M aterials and M ethods}

\section{A nimals}

Theanimal s havebeentaken for these studies have been clinically healthy and sexually matureBlack Bengal bucksof 2- 4years of ageand has an average body weight of 20Kg showing no parasitic infestation. The animals were taken from the local rearers of Jaharhatu $\left(23^{\circ} 21^{\prime} 6^{\prime \prime} \mathrm{N}, 86^{\circ} 2^{\prime} 36^{\prime \prime} \mathrm{E}\right)$ village Purulia district and from the Mohanpur farm $\left(22^{\circ} 56^{\prime} \mathrm{N}, 88^{\circ} 31^{\prime} \mathrm{E}\right)$ of Nadia district, both from the state of West Bengal but in two different agro-climatic regions, there are no feed restriction to the goats. A nimals were maintained in its ambient condition for four weeks prior to blood sampling[7].

\section{Study A reas}

Planning Commission of India,during 2006has demarcated the geographical area of India into 15 agro-climaticregions. Thepresent studies have been carried out into two agro-climatic zones of India. Theseareas follows:

Purulia, fall under Eastern Plateau and Hillsregion of India [8]. This agro-climatic zoneis Located at the southern tip of Bihar. Thirty per cent of the area is classified as forests and only about a quarter of the area is cultivated. It receives about $1,200 \mathrm{~mm}$ of rainfall annually. Theclimateismoist sub-humid to sub-humid and the soil is red loamy, red and yellow.A verage annual rainfall is varies from 1100 to $1500 \mathrm{~mm}$. The humidity ishigh in monsoon season, from $75 \%$ to $85 \%$. But in hot summer it goes down from $35 \%$ to $25 \%$. Temperature varies over a wide range from $7^{\circ} \mathrm{C}$ in winter to $46.8^{\circ} \mathrm{C}$ in the summer(Table 1$)$. Due to undulated topography just about fifty percent of the total rainfall flows away as run off [8]. Thetotal goat population of Puruliahas been recorded as813191 [9].

N adia, fall under Lower Gangetic Plains region of India [10]. A bout $68 \%$ of the land is cultivated. The soil of this sub-zoneis deltaic alluvial and theclimate is per humid to humid. Annual rainfall ranging between $1,200 \mathrm{~mm}$ and $1,700 \mathrm{~mm}$. The zone has a tropical climate with a short spell of winter season. The hot season lasts from mid-March to mid-June, with the day temperature ranging from $38^{\circ} \mathrm{C}$ to $45^{\circ} \mathrm{C}$ in different parts of this region. Themonsoon arrives by the month of middlejune. Winter extends about threemonths; theaverageminimum temperature not goes down bel ow $10^{\circ} \mathrm{C}($ Table 1$)$. A verage rainfall of this area is 1,435.8mm [10]. Thetotal goat population of N adia has been recorded as 952143[9].

\section{Climatological M easurement}

The three year data on temperature of the study area has been collected from thestatemeteorological department and the mean of the three years with standard deviation was calculated (Table 1) using MS-Excel 2007 and shown here in a tabular form (Table1) [11].

Table 1: Mean maximum and minimum temperature of last three years

\begin{tabular}{|c|c|c|c|c|c|c|c|}
\hline \multirow{10}{*}{$\begin{array}{l}0 \\
\vdots \\
5 \\
+1 \\
0 \\
\frac{1}{0} \\
0 \\
\varepsilon \\
0 \\
0 \\
1\end{array}$} & & & M arch & April & May & June & \\
\hline & \multirow{2}{*}{ Purulia } & M ax (ㅇ) & $40.4 \pm 2.3$ & $42.6 \pm 1.5$ & $42.6 \pm 1.5$ & $38.6 \pm 5.0$ & \\
\hline & & $\operatorname{Min}\left({ }^{\circ} \mathrm{C}\right)$ & $21.6 \pm 10.9$ & $21 \pm 0.7$ & $22.4 \pm 1.1$ & $23.2 \pm 0.8$ & \\
\hline & \multirow{2}{*}{ Nadia } & $\operatorname{Max}\left({ }^{\circ} \mathrm{C}\right)$ & $37 \pm 2.45$ & $38 \pm 1$ & $39.2 \pm 1.5$ & $36 \pm 4.7$ & \\
\hline & & $\operatorname{Min}\left({ }^{\circ} \mathrm{C}\right)$ & $16 \pm 3.9$ & $19.4 \pm 3.3$ & $23.4 \pm 1.5$ & $23.6 \pm 1.3$ & \\
\hline & & & November & D ecember & January & February & \\
\hline & \multirow{2}{*}{ Purulia } & $\operatorname{Max}\left({ }^{\circ} \mathrm{C}\right)$ & $32.0 \pm 1.0$ & $30.8 \pm 2.2$ & $30.0 \pm 2.5$ & $34.6 \pm 2.5$ & \\
\hline & & $\operatorname{Min}\left({ }^{\circ} \mathrm{C}\right)$ & $13.6 \pm 1.1$ & $9.4 \pm 1.7$ & $8.6 \pm 0.9$ & $11 \pm 2.5$ & \\
\hline & \multirow[b]{2}{*}{ Nadia } & $\operatorname{Max}\left({ }^{\circ} \mathrm{C}\right)$ & $31.6 \pm 1.2$ & $28.75 \pm 0.5$ & $28.6 \pm 1.5$ & $32.2 \pm 3.6$ & \\
\hline & & $\operatorname{Min}\left({ }^{\circ} \mathrm{C}\right)$ & $14.4 \pm 2.8$ & $11.5 \pm 1.3$ & $10.2 \pm 1.6$ & $12.6 \pm 3$ & \\
\hline
\end{tabular}

\section{Blood collection and Clinical A nalysis}

The blood have been collected from apparently healthy goats using purposive sampling technique [12]for the year and categorized into two seasons. The seasons include pre-monsoon and postmonsoon. A bout $4 \mathrm{ml}$ of blood was collected by jugular venipuncture from each goat between 12 o'clock to 2 pm under theintensesun using disposable needles (SRS ${ }^{T M}$ Sterivan) and vacutainertubes
(Vacutech)[13].Blood sampleshas been collected once in aweek. Blood samples has been collected always at the same time of the day to avoidcircadian variations[14].The collected blood has been dispensed into vials and labelled accordingly.

The enzyme-linked immunosorbent assay (ELISA)

Theserum was separated by centrifugation at 4000 
rpm for $15 \mathrm{~min}$ and stored at $-20^{\circ} \mathrm{C}$ until analysed. Serum testosterone assayed using ELISA kits (abcam $\left.{ }^{\circledR} a b 108666\right)$. Serum testosterone $(\mathrm{ng} / \mathrm{ml}$ ) has been performed using ELISA technique[15].

\section{Statistical Analysis}

Thestatistical analysis of the data was performed using SPSS 21.01 [16]. A one-way analysis of variance (ANOVA) test has been used to determinetheeffects of seasons on the Black Bengal bucks serum testosterone parameters studied here [17]. Mean separation and standard error has been calculated using MS-Excel 2007.

\section{Results}

During in themonth of $\mathrm{M}$ arch in the season of premonsoon (Table2), thetestosteronehormone level in theserum of Black Bengal bucks has been found lower in Purulia than the data obtained in Nadia, but the difference found has not been significant. Whereas thetestosteronehormonelevel of thebuck serum has been higher in Purulia than Nadia during in the month of A pril (Figure1), hereal so the differencehas not been significant. During in themonth of $M$ ay the testosterone hormone level in the serum of Black Bengal bucks in Puruliahave been reduced to $1.22 \pm$ $0.18 \mathrm{ng} / \mathrm{ml}$ (Table2), which is thelowest value of the testosteronehormone level obtained in the serum of Black Bengal bucks in the present study (Figure 1). Thetestosteronehormonelevel in theserum of Black
Bengal bucks obtained during this time in Purulia has been significantly lower $(\mathrm{P}<0.01)$ than thevalue obtained $(4.51 \pm 0.63 \mathrm{ng} / \mathrm{ml})$ in Nadia. Similar kind of results have been found during in the month of June, herealso thetestosteronehormonelevel in the serum of Black Bengal bucks in Purulia have been found significantly $(P<0.01)$ lower than the testosteronehormonelevel found in theserum of Black Bengal bucks in Nadia (Table2).

On the other hand, during in the season of postmonsoon (Table 3) thetestosteronehormone level in the serum of Black Bengal bucks in Nadia during in themonth of November havebeen found significantly $(\mathrm{P} \varangle 0.01)$ higher than that of Purulia. The value obtained in Nadia i.e. $8.79 \pm 1.3 \mathrm{ng} / \mathrm{ml}$, has been the highest valueof thetestosteronehormonein theserum obtained during the present study (Figure 1). The value of the testosteronehormone found in Purulia $(6.59 \pm 0.41 \mathrm{ng} / \mathrm{ml})$, during in themonth of N ovember al so thehighest valueamong themonths studied here in Purulia (Figure1). Moreor less similar kind of result has been obtained during the month of December, wherethetestosterone hormonelevel in theserum of Black Bengal bucks in $\mathrm{N}$ adia has been found significantly $(\mathrm{P} \varangle 0.05)$ higher than the testosterone level found in Purulia (Table 3). However the data collected on the testosterone hormone level in the serum of Black Bengal bucks obtained during the months of January and February are more or less similar in Purulia and Nadia and there are no significant difference have been observed between them (Table3).

Table 2: The influence of seasonal variation on the testosterone hormone of Black Bengal bucks (Capra aegagrus hircus) during in the season of pre-monsoon

\begin{tabular}{ccccc}
\hline Months & $\begin{array}{c}\text { Purulia }(\mathbf{n g} / \mathbf{m l}) \\
\text { M ean } \pm \text { S.E.M }\end{array}$ & $\begin{array}{c}\text { N adia }(\mathbf{n g} / \mathbf{m l}) \\
\text { M ean } \pm \text { S.E.M }\end{array}$ & M ean \pm S.E.M & P-value \\
\hline March & $2.7 \pm 0.78$ & $3.16 \pm 0.59$ & $2.44 \pm 0.59$ & $0.203 \mathrm{NS}$ \\
April & $2.69 \pm 0.52$ & $2.39 \pm 0.64$ & $2.10 \pm 0.41$ & $0.327 \mathrm{NS}$ \\
May & $1.22 \pm 0.18$ & $4.51 \pm 0.63$ & $2.35 \pm 1.00$ & $0.000000001^{* *}$ \\
June & $2.33 \pm 0.48$ & $6.09 \pm 1.39$ & $3.42 \pm 1.48$ & $0.000004^{* *}$ \\
\hline
\end{tabular}

**: P < 0.01; NS: not significant

Table 3: The influence of seasonal variation on the testosterone hormone of Black Bengal bucks (Capra aegagrus hircus) during in the season of post-monsoon

\begin{tabular}{ccccc}
\hline Months & $\begin{array}{c}\text { Purulia }(\mathbf{n g} / \mathbf{m l}) \\
\text { M ean } \pm \text { S.E.M }\end{array}$ & M ean \pm S.E.M & $\begin{array}{c}\text { O verall }(\mathbf{n g} / \mathbf{m l}) \\
\text { M ean } \pm \text { S.E.M }\end{array}$ & P-value \\
\hline November & $6.59 \pm 0.41$ & $8.79 \pm 1.3$ & $7.82 \pm 1.60$ & $0.0004^{* *}$ \\
December & $3.03 \pm 0.65$ & $3.96 \pm 1.09$ & $2.63 \pm 0.61$ & $0.047^{*}$ \\
January & $2.86 \pm 0.55$ & $2.74 \pm 1.19$ & $2.11 \pm 0.73$ & 0.784 NS \\
February & $2.48 \pm 0.64$ & $2.34 \pm 0.64$ & $2.22 \pm 0.52$ & 0.669 NS \\
\hline
\end{tabular}

*: $\mathrm{P}<0.05$; **: $\mathrm{P}<0.01$; NS: not significant 


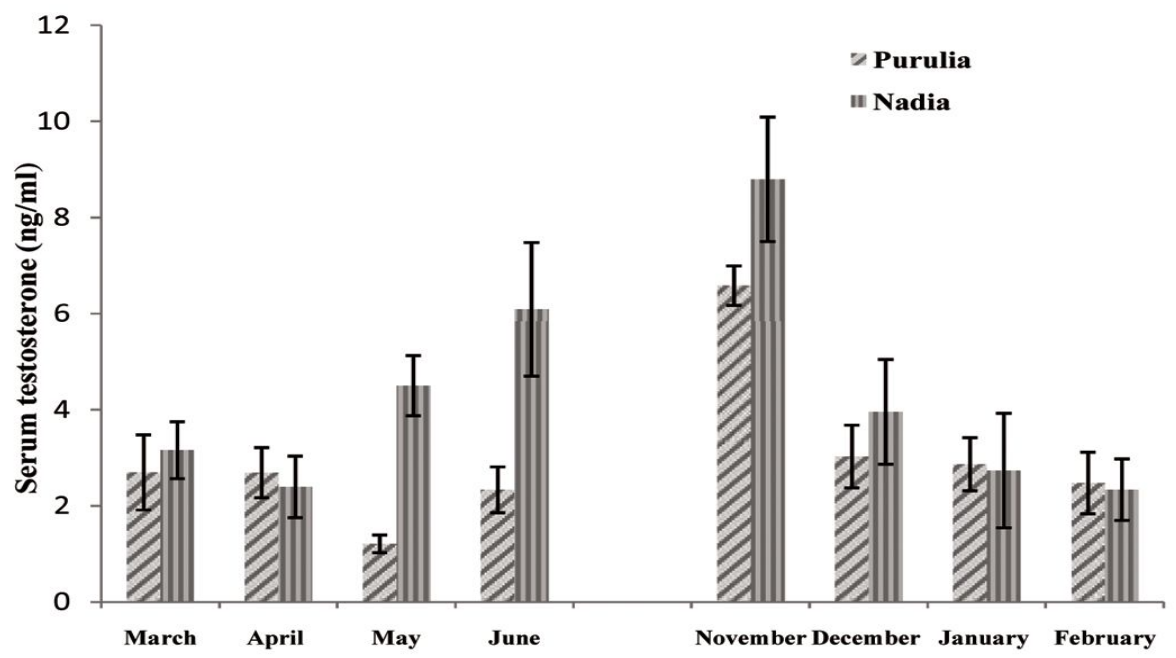

Fig. 1: The diagram itself depicted the influence of seasonal variation on the testosterone hormone of Black Bengalgoats (Capra aegagrushircus) duringin the different months of Pre-monsoon and post-monsoon seasons.

\section{Discussion}

The present study demonstrated that the Black Bengal bucks maintained under two different agroclimatic region show noticeable seasonal variation of testosterone secretion. These variations have beenobserved despite of the animals have been feeding with a similar diet. The results indicate that season strongly influences testosterone secretion of theseanimals. Likesheep, photoperiod or the daylight duration is the principle factor forthe goats'reproduction [18]. The levels of the male or female hormones(hypothalamus to pituitary and subsequently to gonad axis) go through changes depending on thebasis of photoperiod[19]. Likeother mammals, the production of testosteronehormonein goats has beendirectly under the control of Gonadotropin releasinghormone $(\mathrm{GnRH})$ and luteinizing hormone (LH). However thetestosterone hormonelevel in blood generally increases during the breeding period of the bucks.In general all over the worlddoesshow reproductiveactivities mainly in the latemonsoon while the sexual activities stop in premonsoon seasons[20].

During this present study the serum testosterone levels stayed approximately thesamefrom January to March in Purulia and more or less similar in Nadia.However, theserum testosteronelevel reached to its peak level in $\mathrm{N}$ ovember in both theregion $\mathrm{N}$ adia $(8.79 \pm 1.3 \mathrm{ng} / \mathrm{ml})$ and Purulia $(6.59 \pm 0.41 \mathrm{ng} / \mathrm{ml})$ respectively.Del gadillo et al. [21] has been reported that thetestosterone level in Creolebucks in Mexico,has been $0.1 \mathrm{ng} / \mathrm{mL}$ injanuary and February and 10ng/ $\mathrm{mL}$ in July and in August. Low level of testosterone hormonein serum of Black Bengal bucks may bedue to the peak ambient temperatureof thepre-monsoon seasons in the both of theregion.Although it is known that, the reproductive functions of buckshave been generally least dependent on theseasons with respect to the does. So, that during in pre-monsoon season in $M$ ay and Junewherethetestosteronehormonelevel in the serum of Black Bengal bucks in $\mathrm{N}$ adia has been increasing contrasting to the result observed in Purulia. It has been known that the seasonal productionand secretion models aregenerally paralle for most of the goatbreeds, changes in the quantity of the hormone productionhappensmostly due to the latitudeand longitudeand may bedueto other factors likegenotype, feeding habit and feeding leveletc. [22].

Theseasonal influence on plasma testosteroneand the traits of testosterone secretion model had been studied on Verata and Malaguena bucks and were showed an increase in plasma testosterone levels during pre-mosoon and late monsoon, during declining photoperiod [23], this result is however gonediffer from our present findings.

\section{Conclusions}

During the present study it has been observed the lowest testosteronelevelswereobserved from January to A pril for both of the regions of Purulia and Nadia and the month May has the lowest level of the testosterone hormone level in the serum of Black Bengalbucks in Purulia $(1.22 \pm 0.18 \mathrm{ng} / \mathrm{ml})$. However, theserum testosteronelevel reached to its peak level in N ovember in region Nadia $(8.79 \pm 1.3 \mathrm{ng} / \mathrm{ml})$. In this breed i.e. Black Bengal goat, the higher serum testosterone levelhas been reached during the 
decreasing photoperiod and it can beconcluded that month of N ovember and December i.e. early the periods of the post-monsoon season can betaken as an alternate breeding seasons for Black Bengal buck, still a lots of experiment has been needed to established this fact.

\section{Acknowledgement}

The authors are grateful to theHigher Education Department, GOWB and University of Kalyani for funding as well as WestBengal University of A nimal \& Fishery Sciences for othernecessary help. Theauthors also acknowledge the membersof the Institutional Animal Ethical Committee (Department of Zoology, University of Kalyani) for approval the work.

\section{Conflict of the Interest Statement}

None of theauthors has any financial or personal relationshipsthat could inappropriately influenceor bias thecontent of the paper.

\section{References}

1. Otravant R. Photoperiodic regulation of reproduction in the sheep. In: Management of reproduction in sheep and goats symposium, Madison; 1977; 58-71.

2. Hafez E SE. Reproductive behaviour. In: Hafez E SE, ed., Reproduction in Farm A nimals. Lea and Febiger, Philadel phia, USA. 1993; pp. 424-439.

3. Walkden-Brown S.W., Restall B.J. and Henniawati R. The male effect in Australian cashmere goats. 3: Enhancement with buck nutrition and use of oestrous females, A nim. Reprod. Sci.1993; 32(1): 69-84.

4. Shelton M., Reproduction and breeding of goats. J. D airy Sci.1978; 61(1): 994-1010.

5. Mani A.U, Mckelvey W.A.C. and Watson E.D, Effect of undernutrition on gonadotropin profiles in nonpregnant, cycling goats, A nim. Reprod. Sci.1996; 43(1): 25-33.

6. Arnaudov A. Serological survey for Brucellaovis Dissemination among goats (Capra aegagrus hircus) J Centr Euro Agri. 2012; 13(1): 188-192.

7. Bhatta, M., Das, D. and Ghosh P.R. Influence of Seasonal Variation in the General Composition of Black Bengal Goat (Capra aegagrus hircus) Milk, J. D airy, V et A nim. Res.2015; 2 (4): 1-5.

8. Pandey MM. Long-term Strategies and Programmes for Mechanization of Agriculture in Agro Climatic Zone-VII: Eastern Plateau and Hills region, Department of Agriculture \& Co-operation, Ministry of Agriculture. Govt. India. 2006; pp. 144 - 168.
9. Livestock Population: West Bengal Hand book, 2009.

10. Sirohi NPS. Long-term Strategies and Programmes for Mechanization of Agriculture in Agro Climatic Zone-III: Lower Gangetic Plains region, Department of Agriculture \& Co-operation, Ministry of Agriculture. Govt. India. 2006; pp. 96 - 105.

11. Bhatta, M., Das, D. and Ghosh P.R. The Effect of A mbient Temperature on Some Biochemical Profiles of Black Bengal Goats (Capra aegagrus hircus) In Two Different Agro-Climatic Zones in West Bengal, India. IO SR J. Pharm. Biol Sci. 2014; 9(4): 32-36.

12. Tongco MDC. Purposive Sampling as a Tool for Informant Selection, Ethnobotany Res.A ppli. 2007; 5(1):147-158.

13. Bhatta, M., Das, D. and Ghosh P.R. The influence of ambient temperature on thyroid activity, erythrocytic indices and somebiochemical parameters of Black Bengal Goats(Capraaegagrus hircus), Ind. J. Biol. 2014; 1(2): 53 - 58.

14. Anghel, A., Zamfirescu, S., Sogorescu, E., Rotaru, M., Nadolu, D. and Dobrin, N., Seasonal variation of sexual activity on white of banat bucks. A nnals Roman.Soci. Cell Biol., 2012;17(2).

15. Sogorescu, E., Zamfirescu, S., Roooiu, N., A nghel, A.H., and N adolu, D. Seasonal variations of plasma testosteronelevels and testicular volume in Carpathian budks. A fri. J. A gri. Res., 2011; 6(32): 6735-6740.

16. IBM SPSS Statistics 21 Core System User's Guide. IBM. 2012; pp 337-343

17. McDonald, J.H. Hand Book of Biological Statistics. Sparky House Publishing. Baltimore, Maryland. 2008.

18. Malpaux B, Chemineau P and Pelletier J. Melatonin and reproduction in sheep and goat. In: Yu H S, Reiter R J S, eds., M elatonin: Biosynthesis, Physiological Effects and Clinical Applications. CRC Press, Boca Raton Florida, USA. 1992; pp. 254- 287.

19. Hansen, P. J. Photoperiodic regulation of reproduction in mammals breeding during long days versus mammals during short days. A nim.Reprod. Sci., 1985; 9 (1): 301-305.

20. Polat, H., Dellal, G., Baritci, I . and Pehlivan, E. Annual change of the testosterone hormone in male White goats. A gri. Sci. China, 2011; 10(2): 312-316.

21. Delgadillo, J. A., Canedo, G. A., Chemineau, P., Guillaum,eD. andMal paux, B. Evidencefor an annulal reproductive rhythym independent of foot availability in male Creole goats in subtropical northern Mexio. Theriogen ology, 1999; 52(1): 727-737.

22. Todini, L., Malfatti, A., Terzano, G. M., Borghese, A., Pizzillo, M.and Debenedetti, A. Seasonality of plasma testosterone in males of four Mediterranean goat breeds and in three different climatic conditions. Theriogenology, 2007; 67(1): 627-631.

23. Perez, B. andMateos, E. Seasonal variations in plasma testosterone Malaguena bucks. Small Rum. Res., 1995; 15(1): 155-162. 